\title{
What Are the Current Quality Issues in Higher Education?
}

\author{
Elimawaty Rombe \\ Departement of Management \\ University of Tadulako \\ Indonesia \\ rombeelimawaty@untad.ac.id
}

Mirna A. Tolla

Department of Magister Management

University of Tadulako

Indonesia

mirna.atolla@gmail.com

\author{
Patricia Lebona Datu Allo \\ Departement of Management \\ University of Tadulako, acronyms acceptable \\ Indonesia \\ p.lebonna@gmail.com
}

\author{
Septyana Kusuma Dewi \\ Departement of Management \\ University of Tadulako \\ Indonesia \\ Septyana04@yahoo.com
}

\begin{abstract}
Quality is an important part in managing higher education because it can impact on the overall performance. In the recent years, Indonesia Ministry of Education has been planning to improve the quality of higher education especially in business education. This study aims to identify the main quality issues occurred in the process improvement. This study applies analytic hierarchy process to analyze the data. There were thirty students completed the questionnaire from different major studies; accounting, management, and economics. This study found that leadership is the main issue in quality improvement and it is followed by customer service and process management. Thus, the future research should investigate the priority of quality issues in this study to generalize the findings as well as to acknowledge the relationship among factors involve in quality improvement in higher education
\end{abstract}

.Keywords-quality issues, analytic hierarchy process, business education

\section{INTRODUCTION}

In recent years, Indonesia Government has been focusing on improving the accreditation of universities. The main point is that the universities in Indonesia could improve their activities equal to developed universities in South East Asia and Pacific in the following years. In addition, there are only several universities in Indonesia could improve their position in the world ranking. Therefore, it is expected that there are more universities in Indonesia include in the world top rank in the future. In this case, they should focus on overcome their quality issues to obtain this objective.

However, most of universities in Indonesia are difficult to fulfill the international standard. The reason for this, they are difficult to overcome the issues related to service quality in business education, for example, the academic staff competency, quality of infrastructure, management, funding, quality of non-academic staff. Most of academic staff in universities have master degree level compare to developed universities. The quality of infrastructure especially in ICT have not been improved as well as software for supporting learning process in business have not been provided. This situation has large impact on the implementation of e-learning program so that students have difficulty to interact with their lecturers after the class finished.
In addition, students have less access to international journal for improving their papers. The class facilities have also not been improved yet so that students often are interrupted by small breakdown. The capacity of nonacademic staff is also affect their service for students as well as academic staff. Thus, these issues should be solved by most of universities in Indonesia so that the international standard could be achieved.

Hence, the quality issues should be identified and this paper focus on the students side as customer and supplier. The reason for this, students are the customers of university so that they have experience in terms of quality during their period of study. As reference [1] stated that organization has internal customer if there are more than one individual. The internal customer as part of chain act as customer, processor and supplier [2]. In education sector, the customer is divided into primary and secondary [3]. However, some scholars disagree if student is categorized as customer [4]. This paper aims to analyze several quality issues in Indonesia business education, such as, leadership, process management, and service quality. These quality issues are categorized as the priorities. In addition, the criteria in this research, include policies, competency of academic staff and non-academic staff, student activities, facilities support.

This paper is structured as follows: firstly, we explain the current situation in education sector in Indonesia. Secondly, we will discuss the quality in education sector and possible issues of managing higher education. Thirdly, we will describe the research methodology include the AHP approach. Fourthly, we will present the result of study as well as interpretation. Finally, we finish by assessing the most priority of quality issues in business education in Indonesia.

\section{LITERATURE REVIEW}

\section{A. Quality Issues In Higher Quality}

Quality is one of the main factors of business excellence because quality has significant impact on the sustainability of organization. Quality is a part of strategy to sustain customer loyalty as well as maintain overall business performance. Reference [5] argue that good or service has technical quality if the good or service has high technical standard and specifications and fulfill the customers' need. The present 
scholar also argues that good or service has functional quality if good or service has been appropriately delivered and sustains the relationship with customer. Managing higher education is not simple because there are several obstacles need to overcome. The obstacles include structure, personalities, students, academic staff, university staff and management [6]. Furthermore, reference [7] introduced five quality dimensions $(5 \mathrm{Qs})$ which are divided into: quality of object, quality of processes, quality of infrastructure, quality of interaction, and quality of atmosphere. These dimensions reflect that technical and functional quality has relationship to student satisfaction.

\section{B. Leadhership}

Each organization needs a leader to lead organization to achieve the goals. For example, leader plays an important role to increase satisfaction of workers in the work place [8]. In this case, leader creates a better environment for workers so that they could improve their capability and competencies to conduct their tasks or serve the customers. Therefore, reference [9] argued that leadership should have fourth capabilities include ability to influence, motivate, change the attitude, and behavior of subordinate. In addition, the quality leader in service sector should have vision, standards, integrity and involve in the process [10]. Reference [11] found those leaders are expected to be more subordinate the teachers, staff, and students to conduct their activities in order to achieve the objective. Thus, leader has strong relationship to the performance of organization.

\section{Process Management}

Each organization needs a leader to lead organization to achieve the goals. For example, leader play an important role to increase satisfaction of workers in the work place [8]. In this case, leader creates a better environment for workers so that they could improve their capability and competencies to conduct their tasks or serve the customers. Therefore, reference [9] argued that leadership should have fourth capabilities include ability to influence, motivate, change the attitude, and behavior of subordinate. In addition, the quality leader in service sector should have vision, standards, integrity and involve in the process [10]. Reference [11] found that leader are expected to be more subordinate the teachers, staff, and students to conduct their activities in order to achieve the objective. Thus, leader has strong relationship to the performance of organization.

\section{Customer Services}

Students are the part of the successful of higher education and act as customers so that they are so important compare to other stakeholders [14]. Reference [14] claim that objectives of organization could be achieved as long as the customer services are also improved. As reference [14], there are several activities support customer services in higher education, for example, the relationship between students and academic staff, administration staff and students, facilities and equipment, counseling, extracurricular, and others. These activities have strong relationship to the satisfaction of students. This satisfaction is referring to the students' perception and opinion about learning process [15]. Therefore, the more students happy the more satisfy students during learning process. In addition, reference [16] concludes that students expect more interaction between academic staff and students. There are several dimensions impact the relationship between academic staff and students include tangibility, competence, attitude, content, delivery, reliability [4]. The last researchers comprise dimensions, such as, tangibility (adequate equipment and facilities), competence (teaching expertise, practical and theoretical knowledge), attitude (understanding students' needs, courtesy, personal attention, willingness to help), content (practical relevance of curriculum, being cross disciplinary, flexibility of knowledge), delivery (effective presentation, feedback from students, encouraging students), reliability (trustworthiness, handling complaints, solving problems). It is important to note that there are some obstacle to maximize customer service and other activities [17]. Therefore, students have been nominated by experts as an important entity in higher education institutions to improve their customer services

\section{METHODOLOGY}

This study aims to identify the particular quality issues which can impact on school of business performance. This study is categorized as descriptive study because the causal relationships among variables were not tested. The focus of this study is to prioritize the main issues in quality in a Faculty of Economics and Business in Indonesia. The data was collected by one to one interview of different students in major of accounting, management and economics at Faculty of Economics and Business in Indonesia. Non probability judgmental sampling as a method to identify the respondents. The identification process was conducted by considering several categories, such as, the period of study and major of study. Therefore, there were thirty respondents completed the questionnaire in this study. The AHP scale 1-9 was used in the questionnaire as follow.

TABLE I. NINE-POINT PAIR WISE COMPARISON SCALE

\begin{tabular}{|c|l|}
\hline $\begin{array}{c}\text { Numerical } \\
\text { Value }\end{array}$ & \multicolumn{1}{c|}{ Definition } \\
\hline 1 & equal importance \\
\hline 3 & weak importance over one another \\
\hline 5 & strong importance \\
\hline 7 & very strong importance \\
\hline 9 & absolute or extreme importance \\
\hline $2,4,6,8$ & intermediate values between two adjacent judgements \\
\hline
\end{tabular}

The data was analyzed by following several steps. Firstly, the goal, criteria, and alternatives are identified. Secondly, the pair wise comparison matrices of all criteria and alternatives are constructed. Thirdly, the weights of criteria and local weight are determined by using normalization procedure. Finally, local weight are synthesized and it is followed by normalize the global weights. All the data was processed on Microsoft Excel Software. 
TABLE II. THE STAGES OF AHP HIERARCHY

\begin{tabular}{|c|c|c|}
\hline Goal & Criteria & Priority \\
\hline \multirow{4}{*}{$\begin{array}{c}\text { Determine the } \\
\text { quality issues } \\
\text { in business } \\
\text { education }\end{array}$} & Policies & \multirow{2}{*}{ Leadership } \\
\cline { 2 - 2 } & $\begin{array}{c}\text { Competency of Academic } \\
\text { Staff }\end{array}$ & \\
\cline { 2 - 2 } & $\begin{array}{c}\text { Competency of Non } \\
\text { Academic Staff }\end{array}$ & $\begin{array}{c}\text { Process } \\
\text { Management }\end{array}$ \\
\cline { 2 - 2 } & Student Activities & \multirow{2}{*}{ Customer Service } \\
\cline { 2 - 2 } & Facilities Support & \\
\hline
\end{tabular}

\section{RESUlTS AND DISCUSSION}

The following table 3 . depicts the pair-wise comparison of quality issues criteria. It can be seen that policies $(39.77 \%)$ is the number one priority. Then, competency of academic staff $(23.70 \%)$ is the second priority, while competency of nonacademic is the third place $(14.40 \%)$. In addition, facilities support and student activities are the fourth and fifth priority of quality issues with $11,27 \%$ and $10,86 \%$ consecutively.

\section{TABLE III. PAIRWISE COMPARISON QUALITY ISSUES CRITERIA}

\begin{tabular}{|c|c|c|}
\hline Criteria & Local Weights & Priority \\
\hline Policies & 0,397741 & 1 \\
\hline Competency of Academic Staff & 0,236991 & 2 \\
\hline $\begin{array}{c}\text { Competency of Non Academic } \\
\text { Staff }\end{array}$ & 0,143974 & 3 \\
\hline Student Activities & 0,108562 & 5 \\
\hline Facilities Support & 0,112732 & 4 \\
\hline
\end{tabular}

Meanwhile, table 4 shows that most of respondents claim that leadership is the main issue of quality in terms of policies $(37,06 \%)$, while the item of customer service has higher proportion in terms of competency of academic staff $(26,49 \%)$. In addition, the respondents chose process management in terms of competency of non-academic staff $(16,29 \%)$, student activities $(14,75 \%)$, and facilities support $(12,87 \%)$. The table also shows that most of respondents claim that process management is one of important criteria in order to improve quality. In other words, there are issues related to process management in students' opinion.

TABLE IV. PAIRWASE COMPARISON OF ALTERNATIVE BASED EACH CRITERIA

\begin{tabular}{|c|l|c|c|c|c|}
\hline & Policies & $\begin{array}{c}\text { Competency } \\
\text { of } \\
\text { Academic } \\
\text { Staff }\end{array}$ & $\begin{array}{c}\text { Competency } \\
\text { of Non } \\
\text { Academic } \\
\text { Staff }\end{array}$ & $\begin{array}{c}\text { Student } \\
\text { Activities }\end{array}$ & $\begin{array}{c}\text { Facilities } \\
\text { Support }\end{array}$ \\
\hline Leadership & $\mathbf{0 , 3 7 0}$ & 0,228 & 0,149 & 0,134 & 0,119 \\
\hline $\begin{array}{c}\text { Process } \\
\text { Management }\end{array}$ & 0,337 & 0,223 & $\mathbf{0 , 1 6 3}$ & $\mathbf{0 , 1 4 8}$ & $\mathbf{0 , 1 2 9}$ \\
\hline $\begin{array}{c}\text { Customer } \\
\text { Service }\end{array}$ & 0,354 & $\mathbf{0 , 2 6 5}$ & 0,151 & 0,130 & 0,101 \\
\hline
\end{tabular}

Furthermore, the global weight should be measured with the aim to identify the main issue of quality in business education. Most of the respondents claim that leadership is the main issue in terms of quality in business education $(25,08 \%)$. Meanwhile, customer service is chosen as the second place by $25,07 \%$. What is more, the respondents prefer process management as the third issue in business education by $24,12 \%$
TABLE V. GLOBAL WEIGHTS OF THE PRIORITY OF QUALITY ISSUES

\begin{tabular}{|c|c|c|}
\hline Quality Issues & $\begin{array}{c}\text { Global } \\
\text { Weights }\end{array}$ & Priority \\
\hline Leadership & $\mathbf{0 , 2 5 0 8 1 6}$ & 1 \\
\hline Process Management & $\mathbf{0 , 2 4 1 2 2 9}$ & $\mathbf{3}$ \\
\hline Customer Service & $\mathbf{0 , 2 5 0 6 7 6}$ & $\mathbf{2}$ \\
\hline
\end{tabular}

\section{CONCLUSION}

There are many factor can impact quality improvement. Most of scholars conclude that leadership plays an important role in improving quality in organization. The leader leads the transformation of organization to improve their quality of product or services. The leader manages the interconnection of all resource to improve the overall performance of organization. This study also found that leadership is the main priority in business education compare to customer service and process management issue. Most of respondents claim that the faculty has not provide better service in terms of providing high qualified academic staff. Respondents also claim that non- academic staff have not provide proper service in the management process. In addition to this, student activities as well as facilities support have not been improved yet. However, the priority of this study is based on a case study so that it is difficult to generalize. Therefore, the future research should enlarge the criteria as well as sub criteria to obtain the better result. The findings of this study can be used by decision maker in higher education to identify the quality issue so that it will contribute to improve accreditation.

\section{REFERENCES}

[1] Juran, J.M. (1974). Quality Control Handbook (New York, McGrawHill).M. Young, The Technical Writer's Handbook. Mill Valley, CA: University Science, 1989.

[2] Oakland, J.S. (1989). Total Quality Management, 2nd edn. (Oxford,Butterworth)

[3] Gopal K. Kanji , Abdul Malek \& Bin A. Tambi. (1999). Total Quality Management in UK Higher Education Institutions, Total Quality Management, 10:1,129-153, doi: 10.1080/0954412998126

[4] Owlia, M., Aspinwall, E. (1996). A Framework for the Dimensions of Quality in Higher Education. Quality Assurance in Education, 4, 12-20.

[5] Gronroos, C. 2000. Service Management and Marketing: A Customer Relationship Management Approach (Chichester, Wiley).

[6] Zineldin, Mosad., Hatice Camgoz Akdag \& Valentina Vasicheva.(2011). Assessing quality in higher education: new criteria for evaluating students' satisfaction, quality in higher education, 17:2, 231243, doi: 10.1080/13538322.2011.582796.

[7] Zineldin, M. 2000. Total Relationship Management. (Växjö, Sweden,Studentlitteratur, Växjö University).

[8] John, G. \& Saks, A.M. 2005. Organizational Behavior: Understanding and Managing Life at Works. Ed. Ke-6. Toronto: Prentice Hall.

[9] Yahya, Don. 2005. Kepemimpinan Pendidikan di Malaysia. Gombak:PTS Profesional.

[10] Zeithaml, Parasuraman \& Berry. 1990. Delivering Quality Service. New York: Macmillan Publisher.

[11] Rosima Alias, Mohd Hanapiah Ismail, Nurhanis Sahiddan. A Measurement Model for Leadership Skills using Confirmatory Factor Analysis (CFA), Global Conference on Business \& Social Science-2014, 
GCBSS-2014, 15th \& 16th December, Kuala Lumpur, Procedia-Social and Behavioral Sciences 172 ( 2015 ) 717 - 724.

[12] Dragan, M., Ivana, D., \& Arba, R. (2014)., 21st International Economic Conference (IECS), 16-17 May 2014, Sibiu, Romania.

[13] Lafuente, L.; et al. (2012)Satisfaction with Higher Education of Spanish Graduates in the Pre-Bologna Era: A Mirror of Employment Conditions, Journal of Further and Higher Education, Springer, Vol. 36, No.4,p.519-534.

[14] Senthilkumar, N., \& Arulraj, A. (2011). SQM-HEI- determination of service quality measurement of higher education in India. Journal of Modelling in Management, 6(1), 60-78.

[15] Gandolfo Dominici, Federica Palumbo, 2013. How to build an elearning Product:Factors for Student/Customer Satisfaction, Business Horizons, pp 87-96.

[16] Cook, M. (1997). A Student's Perspective of Service Quality in Education. Total Quality Management, 8, 120-125.

[17] Kotler, P., Marketing Management, 15 edition., Pearson 